\title{
Use of alcohol before and after bariatric surgery
}

\section{Uso de bebida alcoólica em períodos pré e pós- operatório de cirurgia bariátrica}

Ana Carolina Ribeiro de Amorim'; Amanda Fernandes Oliveira de Souza'; Ana luisa Valadares Nascimento'; Regiane Maio'; Maria Goretti Pessoa de Araújo Burgos ${ }^{1}$

\section{A B S S T R A C T}

\begin{abstract}
Objective: to assess alcohol intake in the bariatric surgery pre and postoperative periods. Methods: Patients were interviewed atSurgery Clinic of the Hospital das Clínicas da Universidade Federal de Pernambuco - HC/UFPE (Brazil) from July 2011 to March 2012. We analyzed socioeconomic, anthropometric and clinical variables. We used the Alcohol Use Disorders Identification Test (AUDIT C). Results: One hundred nineteen patients were enrolled (mean age: $41.23+11.30$ years), with a predominance of the female gender (83.2\%), non-Caucasian race (55\%), married individuals or in a stable union (65.5\%), with a high school education (40.3\%)and active in the job market (37\%). Weight and body mass index (BMI) were $128.77+25.28 \mathrm{Kg}$ and $49.09+9.26 \mathrm{Kg} / \mathrm{m}^{2}$, respectively in the preoperative period (class II obesity) and $87.19+19.16 \mathrm{Kg}$ and $33.04+6.21 \mathrm{Kg} / \mathrm{m}^{2}$, respectively in the postoperative period (class I obesity) $(p<0.001)$. Hypertension was the most frequent disease in the pre $(66.6 \%)$ and postoperative $(36.5 \%)$ periods. The prevalence of alcohol use was $26.6 \%$ in the preoperative period, of which $2.2 \%$ of high risk, and $35.1 \%$ in the postoperative period, of which $1.4 \%$ of probable dependence; this difference did not achieve statistical significance $(p=0.337)$. Conclusion: The prevalence of abusive alcohol intake and/or probable dependence was low in both the pre and postoperative periods, with little evidence of risky consumption among the patients submitted to bariatric surgery.
\end{abstract}

Key words: Obesity, Morbid. Bariatric Surgery. Alcoholic Beverage. Ethanol. Weight Loss.

\section{INTRODUCTION}

O besity is a non-transmissible chronic disease characterized by excessive accumulation of body fat $^{1}$. It is a multifactorial condition that involves genetic, behavioral, psychological, social, metabolic and endocrine components $^{2}$.

In its most severe form, it is called morbid obesity, where the body mass index (BMI) is above $40 \mathrm{~kg} / \mathrm{m}^{2}$ and it is a risk factor for developing type 2 diabetes mellitus, hypertension, congestive heart failure, dyslipidemia and atherosclerosis, arthropathies, hypoventilation, sleep apnea syndrome and other diseases that diminish patients' quality of life and self-esteem ${ }^{2,3}$.

Nutritional counseling, the practice of regular physical activity and the use of anti-obesity drugs are the basis for weight loss. However, patients with morbid obesity are unable to maintain this weight loss and therefore do not reduce comorbidities. In this scenario, bariatric surgery has shown to be the best treatment with regard to weight loss and maintenance of long-term and comorbidities ${ }^{4}$.

In recent years, some reports have hypothesized that individuals who underwent surgical treatment of obesity could be at increased risk for alcohol abuse after the operation. This could occur due to inability to continue past eating habits and consume large amounts of palatable foods, generating a search for reward in food like substances, such as alcohol ${ }^{5-10}$. Some authors also hypothesized to be a correlation between weight loss after the operation and the consumption of alcohol ${ }^{5,7}$, but there is still no consensus in the literature.

Given the contradictory results and the lack of Brazilian studies on this subject, the objective of this study was to investigate the prevalence of alcohol consumption in bariatric surgery pre and postoperative periods and if there is difference in alcohol consumption between these periods.

\section{METHODS}

We conducted a prospective, case-series study involving 119 patients (45 preoperatively to 74 postoperatively), undergoing Roux en- $Y$ gastric bypass at the surgical clinic of the HC/UFPE from July 2011 to March 2012. We included patients of both genders, aged over 20 years, and excluded those with severe psychiatric disorders, reoperation for complications of the previous procedure and those who underwent abdominoplasty.

1. Department of Nutrition, Universidade Federal de Pernambuco, Recife, Pernambuco State, Brazil. 
The research was conducted after approval by the Ethics in Research Committee of the UniversidadeFederal de Pernambuco, registry SISNEP FR 410772 , in obedience to the 196/96 Resolution of the National Health Council on "Research involving Human Subjects". Participation in the study was voluntary, after obtaining the consent of the patients by signing of a consent form.

Data collection was done through interviews and transcription of information from medical records. The socioeconomic variables studied were: city, age, gender, ethnicity, marital status, educational level and occupational status. The anthropometric assessment was carried from data on height and the higher weight achieved preoperatively, collected from medical records, to calculate the body mass index (BMI), classified according to the criteria of the American Society for Bariatric Surgery ${ }^{11}$.

Wemeasured the preoperative weight and current weight in times $d^{\prime \prime} 3$ months, 3-6 months, $6-12$ months and 12-18 months postoperatively. The percentage of loss of excess weight was calculated using the equation:\% loss of excess weight $=$ (preoperative weight - current weight $\times 100$ ) / preoperative weight - ideal weight. The classification followed the criteria of Higa et al. ${ }^{12}$, who consider appropriate the loss of $15 \%$ in three months, 35\% at six months and $65 \%$ to $75 \%$ between 12 and 18 months after the procedure. The clinical data assessed were: diabetes mellitus, dyspnea, sleep apnea, dyslipidemia, gastroesophageal reflux, menstrual changes, endocrine disorders and hypertension. These were referred to by patients at the time of the interview.

For assessment of alcohol consumption, the interviewee was initially questioned whether he/she made use of alcohol and, in positive cases, the questionnaire AUDIT $C^{13}$ was applied; we further assessed the type of drink, how the patient used and its association with or without food.

We used the Pearson's Chi-square test or Fisher's exact test when the conditions for the Chi-square test were verified, and the Student $t$ test, for independent samples.

\section{RESULTS}

Among the 119 patients studied, 79 (66.4\%) were in the Metropolitan Region of Recife, with a mean age $41.23+11.30$ years60 (50.4\%) between 20 and 39 years. Females presented in greater proportion, $83.2 \%$ of patients, 55\% non-white, $65.5 \%$ were married or were in stable union, $40.3 \%$ attended up to high school and $37 \%$ were in the active labor market. The weight in the preoperative period was $128.77 \pm 25.28 \mathrm{Kg}$ and the BMI, $49.09 \pm 9.26 \mathrm{Kg} / \mathrm{m}^{2}$, classified as class III obesity, and in the postoperative period, $87.19 \pm 19.16 \mathrm{Kg}$ and $\mathrm{BMI}$, $33.04 \pm 6.21 \mathrm{Kg} / \mathrm{m}^{2}$, classified as class I obesity, with $\mathrm{p}<0.001$. Hypertension was the most common associated disease (Table 1).

We found that in the preoperative period $26.6 \%$ of patients consumed alcoholic beverages, and in the postoperative period, $35.1 \%$. There was no statistical difference between groups, $p=0.337$. The risk classification of alcohol use according to the AUDIT $C$ showed that the majority of patients were at low risk, both before and after the bariatric procedure (Table 2 ).

The most widely used type of beverage before $(91.6 \%)$ and after surgery (88.5\%) was beer. Among the respondents, $91.6 \%$ of the preoperative group and $88.5 \%$ of the postoperative group consumed food during alcohol intake. The peanut was the most consumed food before surgery $(91.6 \%)$ and the whole cheese, after (73.1\%). A low percentage did not eat before drinking, and $16.6 \%$ in the preoperative period and $11.5 \%$ in the postoperative one. We have not found any significant result between drinking habits in the pre and postoperative periods and their association with the socioeconomic variables studies (Tables 3 and 4).

The percentage of excess weight loss in the times $<3$ months, 3-6 months, 6-12 months and 12-18

Table 1 - Prevalence of diseases and clinical disorders pre and postoperatively.

\begin{tabular}{|c|c|c|}
\hline Associated diseases, clinical disorders & $\begin{array}{c}\text { Pre }(N=45) \\
N(\%)\end{array}$ & $\begin{array}{c}\text { Post }(\mathrm{N}=74) \\
\mathrm{N}(\%)\end{array}$ \\
\hline Hypertension & 30 (66.6) & $27(36.5)$ \\
\hline Dyspnoea & 21 (46.6) & $5 \quad(6.8)$ \\
\hline Menstrual Changes & $16(42.1)$ & $8(10.8)$ \\
\hline GastroesophagealReflux & $17(37.7)$ & $8(10.8)$ \\
\hline Sleep Apeia & $13(28.8)$ & $1 \quad(1.4)$ \\
\hline Dyslipidemia & $12(26.6)$ & $7 \quad(9.5)$ \\
\hline Diabetes Mellitus & $11(24.4)$ & $3 \quad(4.1)$ \\
\hline Endocrine Diseases & $2 \quad(4.4)$ & $5 \quad(6.8)$ \\
\hline
\end{tabular}


Table 2 - $\quad$ Classification of AUDIT C in patients who drank alcohol.

\begin{tabular}{lcrrrr}
\hline Classification of AUDIT C & \multicolumn{2}{c}{ Pre $(\mathrm{N}=12)$} & \multicolumn{2}{c}{ Post $(\mathrm{N}=26)$} \\
& $\mathbf{N}$ & $\mathbf{( \% )}$ & $\mathbf{N}$ & $(\%)$ \\
\hline Low Risk/Abstemious & 9 & 75.0 & 17 & 65.4 \\
Risk & 2 & 16.7 & 8 & 30.8 \\
Harmful/High Risk & 1 & 8.3 & - & - \\
Likely Dependence & - & - & 1 & 3.8 \\
\hline
\end{tabular}

months showed no association with alcohol consumption (Table 5).

\section{DISCUSSION}

In 2005, people drank up the equivalent of 6.1 liters of pure alcohol per person all over the world ${ }^{13}$. Brazil ranks fourth in alcohol consumption in the Americas, with an average of 18.5 liters of pure alcohol / year. According to the Ministry of Health ${ }^{14}$, in 2011 16\% of the Brazilian population used alcohol. Data in obese patients ${ }^{9}$ suggest that less than $3 \%$ of patients may develop alcohol problems.

Among the socioeconomic variables, we saw a predominance of females, similar to the Brazilian studies of Prevedelloet al. ${ }^{2}$ and Barhouchet al. ${ }^{3}$. This is probably due to the greater concern of women with weight, health, in addition to the high prevalence of overweight in Brazilian patients, especially among those of less favorable conditions ${ }^{15}$. The average age and race

Table 3 - Association of the use of alcoholic beverages in the preoperative period with socioeconomic factors.

\begin{tabular}{|c|c|c|c|c|c|c|c|}
\hline \multirow{3}{*}{ Variable } & \multicolumn{6}{|c|}{ Habit of alcoholism } & \multirow{3}{*}{$p$ value } \\
\hline & \multicolumn{2}{|c|}{ Yes } & \multicolumn{2}{|c|}{ No } & \multicolumn{2}{|c|}{ TOTAL } & \\
\hline & $\mathrm{n}$ & $\%$ & $\mathrm{n}$ & $\%$ & $n$ & $\%$ & \\
\hline \multicolumn{7}{|l|}{ Age group } & \\
\hline Up to 39 & 9 & 34.6 & 17 & 65.4 & 26 & 100.0 & $\mathrm{p}^{(1)}=0.458$ \\
\hline 40 to 49 & 2 & 16.7 & 10 & 83.3 & 12 & 100.0 & \\
\hline 50 or more & 1 & 14.3 & 6 & 85.7 & 7 & 100.0 & \\
\hline \multicolumn{8}{|l|}{ Gender } \\
\hline Male & 2 & 28.6 & 5 & 71.4 & 7 & 100.0 & $p^{(1)}=1.000$ \\
\hline Female & 10 & 26.3 & 28 & 73.7 & 38 & 100.0 & \\
\hline \multicolumn{8}{|l|}{ Race } \\
\hline Caucasian & 5 & 38.5 & 8 & 61.5 & 13 & 100.0 & $\mathrm{p}^{(1)}=0.285$ \\
\hline \multicolumn{8}{|l|}{-Marital status } \\
\hline Single & 1 & 33.3 & 2 & 66.7 & 3 & 100.0 & $\mathrm{p}^{(1)}=1.000$ \\
\hline $\begin{array}{l}\text { Married } \\
\text { Schooling }\end{array}$ & 11 & 26.2 & 31 & 73.8 & 42 & 100.0 & \\
\hline Elementary school & 5 & 25.0 & 15 & 75.0 & 20 & 100.0 & $\mathrm{p}^{(1)}=0.817$ \\
\hline High school & 4 & 23.5 & 13 & 76.5 & 17 & 100.0 & \\
\hline Higher education & 3 & 37.5 & 5 & 62.5 & 8 & 100.0 & \\
\hline Occupation & & & & & & & \\
\hline Employee/Self-employed & 6 & 37.5 & 10 & 62.5 & 16 & 100.0 & $\mathrm{p}^{(1)}=0.339$ \\
\hline Unemployed & 2 & 13.3 & 13 & 86.7 & 15 & 100.0 & \\
\hline Retired/Benefit & 1 & 14.3 & 6 & 85.7 & 7 & 100.0 & \\
\hline $\begin{array}{l}\text { Of home } \\
\text { Origin }\end{array}$ & 3 & 42.9 & 4 & 57.1 & 7 & 100.0 & \\
\hline Recife/Surroundings & 8 & 28.6 & 20 & 71.4 & 28 & 100.0 & $\mathrm{p}^{(1)}=1.000$ \\
\hline Upstate & 4 & 23.5 & 13 & 76.5 & 17 & 100.0 & \\
\hline
\end{tabular}

(1) Fisher's exact Test. 
Table 4 - Association of use of alcoholic beverages in the postoperative period with socioeconomic factors.

\begin{tabular}{|c|c|c|c|c|c|c|c|}
\hline \multirow{3}{*}{ Variable } & \multicolumn{6}{|c|}{ Habit of alcoholism } & \multirow{3}{*}{$p$ value } \\
\hline & \multicolumn{2}{|c|}{ Yes } & \multicolumn{2}{|c|}{ No } & \multicolumn{2}{|c|}{ TOTAL } & \\
\hline & $\mathrm{n}$ & $\%$ & $\mathrm{n}$ & $\%$ & $\mathrm{n}$ & $\%$ & \\
\hline \multicolumn{8}{|l|}{ Age group } \\
\hline Up to 39 & 15 & 44.1 & 19 & 55.9 & 34 & 100.0 & $p^{(1)}=0.288$ \\
\hline 40 to 49 & 6 & 31.6 & 13 & 68.4 & 19 & 100.0 & \\
\hline \multicolumn{8}{|l|}{ Gender } \\
\hline Male & 6 & 46.2 & 7 & 53.8 & 13 & 100.0 & $\mathrm{p}^{(2)}=0.361$ \\
\hline \multicolumn{8}{|l|}{ Race } \\
\hline White & 7 & 30.4 & 16 & 69.6 & 23 & 100.0 & $\mathrm{p}^{(1)}=0.570$ \\
\hline \multicolumn{8}{|l|}{ Marital status } \\
\hline Single & 10 & 26.3 & 28 & 73.7 & 38 & 100.0 & $p^{(1)}=0.103$ \\
\hline \multicolumn{8}{|l|}{ Schooling } \\
\hline Illiterate & 2 & 40 & 3 & 60 & 5 & 100.0 & $\mathrm{p}^{(2)}=0.902$ \\
\hline Elementary school & 7 & 33.3 & 14 & 66.7 & 21 & 100.0 & \\
\hline High school & 10 & 32.3 & 21 & 67.7 & 31 & 100.0 & \\
\hline Higher education & 7 & 41.2 & 10 & 58.8 & 17 & 100.0 & \\
\hline \multicolumn{8}{|l|}{ Occupation } \\
\hline Employee/Self-employed & 12 & 42.9 & 16 & 57.1 & 28 & 100.0 & $\mathrm{p}^{(2)}=0.524$ \\
\hline Unemployed & 7 & 30.4 & 16 & 69.6 & 23 & 100.0 & \\
\hline Retired/Benefit & 3 & 21.4 & 11 & 78.6 & 14 & 100.0 & \\
\hline Of home & 4 & 44.4 & 5 & 55.6 & 9 & 100.0 & \\
\hline \multicolumn{8}{|l|}{ Origin } \\
\hline Recife/ Surroundings & 19 & 37.3 & 32 & 62.7 & 51 & 100.0 & $\mathrm{p}^{(2)}=0.871$ \\
\hline Another State & 4 & 30.8 & 9 & 69.2 & 13 & 100.0 & \\
\hline Upstate & 3 & 30 & 7 & 70 & 10 & 100.0 & \\
\hline
\end{tabular}

(1) Pearson Chi-square Test; (2) Fisher's exact Test.

differ from the findings of Costa et al. ${ }^{16}$, who observed, in a group of patients in the pre and postoperative periods, an average age of $36.07 \pm 10.16$ years, with a predominance of Caucasians (86.53\%). Herman et al. ${ }^{17}$, detected a predominance of married individuals with professional activity in a bariatric population, data similar to ours. On the other hand, they reported a prevalent low level of education, differing from our results, since most of our patients had completed high school. The preoperative weight average found by Costa et al. ${ }^{18}$ was $138 \pm 28.8 \mathrm{~kg}$ and BMI, $52 \pm 8.6 \mathrm{~kg} / \mathrm{m}^{2}$, while 12 months after surgery, these were $90 \pm 19.5 \mathrm{~kg}$ and $34 \pm 6.6 \mathrm{~kg} /$ $\mathrm{m}^{2}$, respectively, higher than our findings. Hypertension was the most common associated disease, corroborating other studies, where its prevalence was $21.97 \%{ }^{17}$ and $35.9 \%{ }^{19}$

Erteltet al. ${ }^{9}$ observed a low preoperative alcohol consumption, $7.1 \%$ of individuals having alcohol dependency and $1.4 \%$ abusing it, when assessed by the Diagnostic and
Statistical Manual of Mental Disorders IV (DSM IV). In our work, with the AUDIT C we found that $2.2 \%$ of patients were high risk alcohol users preoperatively. In the postoperative period we obtained a percentage of $1.4 \%$, with likely dependency. These are much lower results than the ones of Buffington ${ }^{10}$, according to whom $84 \%$ of patients consumed alcohol after surgery. Data from the First Brazilian survey of alcohol consumption patterns in the Brazilian population ${ }^{20}$ showed that the most consumed beverage in the country was beer (61\%), confirming the pattern found in our patients. According to Wendlinget al. ${ }^{8}$, after surgery, compulsive individuals unable to consume excess food can replace it with alcohol. In our study group, there was no replacement, but the association, with food. When associated with fat or protein foods, there is significant reduction in alcohol absorption ${ }^{21}$, this being a beneficial habit.

As for the use of alcohol and socioeconomic factors, it is evident that although there was no significant 
Table 5 - Classification of the percentage of excess weight loss (\% EWL) associated with the use of alcohol.

\begin{tabular}{|c|c|c|c|c|c|c|c|c|}
\hline \multirow{2}{*}{\multicolumn{2}{|c|}{ Classification of\% EWL }} & \multicolumn{2}{|c|}{ Yes } & \multicolumn{2}{|c|}{ No } & \multicolumn{2}{|c|}{ Total Group } & \multirow[t]{2}{*}{$p$ value } \\
\hline & & $\mathrm{N}$ & $\%$ & $\mathrm{~N}$ & $\%$ & $\mathrm{~N}$ & $\%$ & \\
\hline \multicolumn{9}{|l|}{$<3$ months } \\
\hline Suitable & & 19 & 100.0 & 30 & 93.8 & 49 & 96.1 & $\mathrm{p}^{(1)}=0.523$ \\
\hline Inappropriate & & - & - & 2 & 6.3 & 2 & 3.9 & \\
\hline TOTAL & & 19 & 100.0 & 32 & 100.0 & 51 & 100.0 & \\
\hline \multicolumn{9}{|l|}{ 3-6 months } \\
\hline Suitable & & 17 & 94.4 & 23 & 79.3 & 40 & 85.1 & $\mathrm{p}^{(1)}=0.225$ \\
\hline Inappropriate & & 1 & 5.6 & 6 & 20.7 & 7 & 14.9 & \\
\hline TOTAL & & 18 & 100.0 & 29 & 100.0 & 47 & 100.0 & \\
\hline \multicolumn{9}{|l|}{ 6-12 months } \\
\hline Suitable & & 2 & 20.0 & 8 & 42.1 & 10 & 34.5 & $\mathrm{p}^{(1)}=0.414$ \\
\hline Inappropriate & & 8 & 80.0 & 11 & 57.9 & 19 & 65.5 & \\
\hline TOTAL & & 10 & 100.0 & 19 & 100.0 & 29 & 100.0 & \\
\hline \multicolumn{9}{|l|}{ 12-18 months } \\
\hline Suitable & & 2 & 33.3 & 4 & 66.7 & 6 & 50.0 & $p^{(1)}=0.567$ \\
\hline Inappropriate & & 4 & 66.7 & 2 & 33.3 & 6 & 50.0 & \\
\hline TOTAL & & 6 & 100.0 & 6 & 100.0 & 12 & 100.0 & \\
\hline \multicolumn{9}{|l|}{ End } \\
\hline Suitable & & 11 & 57.9 & 17 & 53.1 & 28 & 54.9 & $p^{(2)}=0.741$ \\
\hline Inappropriate & & 8 & 42.1 & 15 & 46.9 & 23 & 45.1 & \\
\hline TOTAL & & 19 & 100.0 & 32 & 100.0 & 51 & 100.0 & \\
\hline
\end{tabular}

(1) Pearson Chi-square Test; (2) Fisher's exact Test.

association with drinking habits, those who drank were aged up to 39 years (44\%), predominantly male, a fact common at this age in our region in non-operated in men. Higher percentages in this gender were seen in the Ministry of Health research ${ }^{20}$, where $11 \%$ of men consumed alcohol very often and $28 \%$, often.

There is evidence that the consumption of palatable foods produces in the brain effects similar to those produced after alcohol intake ${ }^{22}$. Substances such as sugar or fat cause an increase of endogenous opioids in the mesolimbic reward system and dopamine, although not as dramatically as alcohol and other drugs ${ }^{23}$. The use of alcohol is not predictive of proper weight loss ${ }^{24}$. The percentage ofexcess weight loss after surgery and its association with alcohol, similar to other studies, ${ }^{7,25}$, showed no positive nor negative association with weight loss.

In this sample of bariatric patients in pre and postoperative periods, there was alcohol use prevalence higher than that detected in the Brazilian population. However, we did not observehigh risk consumption / probable dependence, or consumption increase in the postoperative period.

\section{R E S U M O}

Objetivo: avaliar a ingestão de bebidas alcoólicas nos períodos pré e pós-operatório de cirurgia bariátrica. Métodos: os pacientes foram entrevistados no ambulatório de Cirurgia Geral do Hospital das Clínicas/UFPE, no período de julho/2011 a março/ 2012. Foram analisadas variáveis socioeconômicas, antropométricas e clínicas. A avaliação do consumo de álcool nos últimos 12 meses, foi realizada pelo questionário AUDIT C (alcohol use disorders identification test). Resultados: foram estudados 119 pacientes com média de idade de 41,23+11,30 anos, com predominância do sexo feminino (83,2\%), raça não branca (55\%), casados ou em união estável (65,5\%), com ensino médio (40.3\%) e ativo ao mercado de trabalho (37\%). O peso no período préoperatório foi 128,77+25,28Kg e IMC 49,09+9,26Kg/m², classificado em obesidade classe III, e no pós-operatório foi 87,19+19,16Kg e IMC 33,04+6,21 Kg/m², classificado em obesidade classe l, com $p<0,001$. A doença mais frequente no pré (66,6\%) e pós operatório (36,5\%) foi a hipertensão. No período pré-operatório $26,6 \%$ faziam uso de álcool, sendo 2,2\% uso de alto risco e no pós-operatório 35,1\%, sendo 1,4\% provável dependência, não sendo encontrada diferença significativa entre os grupos de pré e pós-cirúrgico $(p=0,337)$. Conclusão: foi encontrada uma prevalência do uso alcoólico superior àquela detectada na população brasileira, no entanto não foi evidenciado consumo de alto risco/provável dependência, nem elevação deste consumo em período pós-operatório.

Descritores: Obesidade Mórbida. Cirurgia Bariátrica. Bebidas Alcoólicas. Etanol. Perda de Peso. 


\section{REFERENCES}

1. Fagundes ALN, Ribeiro DC, Naspitz L, Garbelini LEB, Vieira JKP, Silva AP, et al. Prevalência de sobrepeso e obesidade em escolares da região de Parelheiros do município de São Paulo. Rev paul pedriatr. 2008;26(3):212-7.

2. PrevedelloCF, Colpo E, Mayer ET, Copetti H. Análise do impacto da cirurgia bariátrica em uma população do centro do Estado do Rio Grande do Sul utilizando o método Baros. ArqGastroenterol. 2009;46(3):199-203.

3. Barhouch AS, Zardo M, Padoin AV, Colossi FG, Casagrande DS, Chatkin $\mathrm{R}$, et al. Excess weight loss variation in late postoperative period of gastric bypass. ObesSurg. 2010;20(11):1479-83.

4. Schouten R, Wiryasaputra DC, van Dielen FM, van Gemert WG, Greve JW. Long-term results of bariatric restrictive procedures: a prospective study. Obes Surg. 2010;20(12):1617-26.

5. Heinberg LJ, Ashton K, Coughlin J. Alcohol and bariatric surgery: review and suggested recommendations for assessment and management. SurgObesRelat Dis. 2012;8(3):357-63.

6. Welch G, Wesolowski C, Zagarins S, Kuhn J, Romanelli J, Garb J, et al. Evaluation of clinical outcomes for gastric bypass surgery: results from a comprehensive follow-up study. Obes Surg. 2011;21(1):1828.

7. Suzuki J, Haimovici F, Chang G. Alcohol use disorders after bariatric surgery. Obes Surg. 2012;22(2):201-7.

8. Wendling A, Wudyka A. Narcotic addiction following gastric bypass surgery-a case study. Obes Surg. 2011;21(5):680-3.

9. Ertelt TW, Mitchell JE, Lancaster K, Crosby RD, Steffen KJ, Marino JM. Alcohol abuse and dependence before and after bariatric surgery: a review of the literature and report of a new data set. SurgObesRelat Dis. 2008;5(4):647-50.

10. Buffington CK. Alcohol use and health risks: survey results. BT Online. 2007;4(2):21-3.

11. American Society of Bariatric Surgery. Rationale for surgery(1)1: 13 telas. Available from: URL: http://www.asbs.org

12. Higa KD, Boone KB, Ho T, Davies OG. Laparoscopy Roux-en-Y gastric bypass for morbid obesity: technique and preliminary results of our first 400 patients. Arch Surg. 2000;135(9):1029-33; discussion 1033-4

13. World Health Organization. Global status report on alcohol and health. Switzerland; 2011. p.286.

14. Ministério da Saúde. Vigilância de fatores de risco e proteção para doenças crônicas por inquérito telefônico (Vigitel); 2011.
15. Batista MCR, Franceschini SCC, Priore SE, Avaliação de indicadores antropométricos de adultos e idosos brasileiros. Nutrire Rev Soc Bras Aliment Nutr. 2002;23:67-78.

16. Costa ACC, Ivo ML, Cantero WB, Tognini JRF. Obesidade em pacientes candidatos à cirurgia bariátrica. Actapaulenferm. 2009;22(1):55-9.

17. Germano ACPL, Camelo CMBM, Batista FM, Carvalho NMA, Liberali $R$, Coutinho VF. Perfil nutricional dos pacientes submetidos à cirurgia bariátrica e dos critérios adotados para encaminhamento em um hospital de João Pessoa, PB. Ensaios e Ciência: CiênciasBiológicas, Agrárias e da Saúde. 2011;14(2):43-59.

18. Costa LD, Valezi AC, Matsuo T, Dichi I, Dichi JB. Repercussão da perda de peso sobre parâmetros nutricionais e metabólicos de pacientes obesos graves após um ano de gastroplastia em Y-deRoux. Rev Col Bras Cir. 2010;37(2):96-101.

19. Anderi Júnior $E$, Araújo LGC, Fuhro FE, Godinho CA, Henriques AC. Experiência inicial do Serviço de Cirurgia Bariátrica da Faculdade de Medicina do ABC. ArqMed ABC. 2007;32(1):25-9.

20. Laranjeira R, Pinsky I, Zaleski M, Caetano R. I Levantamento nacional sobre os padrões de consumo de álcool na população brasileira. Brasília: Secretaria Nacional Antidrogas; 2007. p.76.

21. Maillot F, Farad S, Lamisse F. Alcohol and nutrition. Pathol Biol. 2001;49(9):683-8

22. Del Parigi A, Chen K, Salbe AD, Reiman EM, Tataranni PA. Are we addicted to food?Obes Res. 2003;11(4):493-5.

23. Volkow ND, Wise RA. How can drug addiction help us understand obesity? Nat Neurosci. 2005;8(5):555-60.

24. Kopec-Schrader EM, Gertler R, Ramsey-Stewart G, Beumont PJ. Psychosocial outcome and long-term weight loss after gastric restrictive surgery for morbid obesity. Obes Surg. 1994;4(4):3369.

25. Sears D, Fillmore G, Bui M, Rodriguez J. Evaluation of gastric bypass patients 1 year after surgery: changes in quality of life and obesityrelated conditions. Obes Surg. 2008;18(12):1522-5.

Received 20/01/2014

Accepted for publication 15/04/2015

Conflict of interest: none

Source of funding: none

Address for correspondence:

Maria Goretti Pessoa de Araújo Burgos

E-mail: gburgos@hotlink.com.br 